\title{
Inter-State, Intra-State, and Extra-State Wars: A Comprehensive Look at Their Distribution over Time, 1816-1997
}

\author{
Meredith Reid Sarkees \\ Saint Mary's College \\ FRANK WHELON WAYMAN \\ University of Michigan-Dearborn \\ J. DAVID Singer \\ University of Michigan-Ann Arbor
}

\begin{abstract}
Students of world politics disagree about the approaching outlook for war. Are we in the midst of an era of peace with a declining prospect of war, or are we facing a future characterized by increasing "ethnic" conflicts? This puzzle has led scholars to call for a more comprehensive examination of the phenomenon of war. A discussion concerning this need for a new look at war had also arisen within the Correlates of War Project. For more than three decades the Correlates of War Project's database has served the research needs of most of the quantitative world politics community, especially in identifying and trying to account for several classes of war (inter-state, extra-systemic, and civil) throughout the international system since 1816. However, a number of the disagreements in the literature concerning the prospects of war derive from the tendency of many researchers to rely on only one of our data sets (e.g., inter-state war). Here we wish to stimulate a broader view of war by examining the interplay among the three major types of war.

Historical developments of the past half-century, and especially since the end of the Cold War, have rendered the original COW war typology increasingly incomplete. Consequently, we developed a modified typology of war and attempted to format the descriptive variables in ways that would facilitate a more comparative and comprehensive analysis of warfare. While the reader should be reassured that Interstate Wars remain as previously defined, we introduce the term "Intrastate War" in place of our original Civil War category, and the term "Extra-state War" in place of our initial Extra-systemic War category, allowing us to reclassify several such wars. This revised typology coupled with an update of the data allows us to take a fresh look at the question whether, from the perspective of the past two centuries, war is in fact becoming less common. The article concludes with a series of analyses that describe the patterns and trends of all types of war-reflecting the new typology-since the Congress of Vienna. These analyses reflect a disquieting constancy in warfare and hint at patterns of interchangeability or substitutability among the types of war.
\end{abstract}


Is the world characterized more by peace or by war? Is war less of a threat to humanity in our time than in the past? Much of international political theory turns on these questions. The debate between "political realism" and "liberalism" (or "neo-liberalism") revolves in large part around the question of whether war and the threat of war are constant characteristics of world politics. Power politics (or "realpolitik") analysts see the essential features of the international system (anarchy, dominance of the state, insecurity, war) as eternal, while liberals hope that such factors as changing norms, economic growth, and the spread of democracy are rendering war obsolete or at least less common (Oneal and Russett, 1997a; Wayman and Diehl, 1994; Wallensteen, 1984).

Similarly, the theoretical and empirical scholarship on war in particular has been replete with competing understandings concerning the historical trends in warfare and in predictions about the future prospects for war. Many scholars have seen the post-World War II era as one of relative stability with a decrease in warfare (Waltz, 1979; Gaddis, 1987). In the same vein, empirical investigation (focused on interstate war) has examined whether the long postwar (since 1945) peace is indeed distinctive compared to earlier peaceful periods, such as the post-Napoleonic era from 1816 to 1848 and the other long peace from 1870 to 1914 (Kegley, 1991). In particular, research has concentrated on the "causes" of inter-state war, and rich data sets document the correlates of inter-state war relatively well (Cashman, 1993; Midlarsky, 1989; Geller and Singer, 1998). Consequently, much of this research, some of which assumes at least implicitly that war is declining, has gone on to the important tangential questions of whether democracy, international organizations, commerce, norms, or nuclear weapons are the reason for the decline (or even obsolescence) in warfare.

Others, in contrast, have noted that the post-World War II era has witnessed a great deal of warfare. Most brutally, tens of millions have died in combat in the modern era (Small and Singer, 1982), and even more in the acts of genocide, politicide, and democide that often accompany war and are exacerbated by it (Harff and Gurr, 1988; Rummel, 1994). There are those (for instance, Clodfelter, 1992: 971) who claim that both international and civil wars (conventional and guerilla) seem to have made a comeback. Other scholars (frequently more concerned with civil conflict) have focused more specifically on the emergence of possibly new types of war. For instance, Kal Holsti (1996) has argued that we are seeing the emergence of new "wars of the third kind," and others decry the proliferation of "ethnic wars" (Lake and Rothchild, 1998; Carment and James, 1997).

For all these reasons and more, it is vitally important to know whether war is as ubiquitous as some say, declining as fast as others assert, or fluctuating across time and place. Surprisingly, though hundreds of books and articles have tangentially addressed this question in recent years, too few have examined and answered the basic question of whether the data indicate that the total amount of war in the world is increasing, decreasing, or remaining the same. Research endeavors have tended to concentrate on only one type of war, and many of the contradictory conclusions are strongly influenced by the type of war being studied (inter-state or civil). Obviously part of this dichotomy is linked to cleavages in the discipline, with international politics scholars concerned primarily with inter-state wars and comparative politics scholars focusing more often upon internal developments, including revolutions and civil wars (Gurr, 1970; Midlarsky, 1988). The lack of a dialogue between these two realms has limited the accumulation of knowledge and has circumscribed our understanding of war. Particularly, at the end of the Cold War, the more narrow disciplinary focus on inter-state war is no longer justifiable (Eberwein and Chojnacki, 2001:4).

In contrast to these segmented approaches, there are those who see similarities and linkages between intra- and inter-state wars. For example, Snow (1996:1-2) argues that contemporary internal wars are unlike their predecessors due to their 
more violent nature. In fact, he argues that such wars are more like international wars than what were traditionally referred to as civil wars, leading him to call them "uncivil wars." Similarly, Sandole (1991:1) argues that there are significant similarities among violent conflicts occurring at various levels of aggregation, and thus asserts the need for a generic theory for "Capturing the Complexity of Conflict." In this article we attempt such an endeavor; we take a fresh approach by reexamining nearly two centuries of trends in all the forms of modern war that involve state actors-between states, within states, and beyond states. Utilizing the revised Correlates of War data sets, we examine the interplay among three general classes of war: inter-state, extra-state, and civil. While the revised typology (and concomitant data sets) do not perhaps go as far as some critics might prefer, this revision seeks to bridge the need to recognize recent historical change on the one hand while maintaining the continuity essential to the longitudinal research that has been the hallmark of the Correlates of War and the many other projects that have helped create a scientific discipline of the study of war.

\section{Decreasing War Trends}

Many scholars have noted a decreasing propensity for states to go to war. For instance, Levy detected a downward trend in great power wars (wars in which at least one major sovereign state fought on each of the two sides) over the period 1495-1975. He hypothesized that "increasing costs of Great Power war relative to its perceived benefits have reduced its utility as a rational instrument of state policy and largely account for its declining frequency" (1983:148-149). Factors he believed to be influencing this trend included the increasing human and economic costs of war stemming from its greater destructiveness, the declining legitimacy of war, the declining value of territorial conquest, and the increasing congruence between political and ethnic boundaries.

Discussions of the decline in warfare have become more pronounced when dealing with the post-World War II era. A variety of explanations has been offered, both theoretically and empirically, for this trend, including a bipolar structure, economic ties, and the spread of democracy. The four decades of the globalized "Cold War" starting in 1947 did not spark sustained combat nor substantial battle fatalities between the Soviet Union and the United States, and thus did not technically qualify as a "war." Furthermore, Waltz (1979) argued that the bipolarity of the international system during the Cold War era would decrease the frequency and severity of war overall. In the same vein, Mueller (1989) found that the wealthy states (both nuclear and non-nuclear) had stopped fighting each other in the post1945 period. In particular, the forty-eight richest industrial states had had no wars against each other except for the Falklands War in 1982 and the Soviet invasion of Hungary in 1956. The Greek civil war of the late 1940s had been the only civil (or "internal") war among these prosperous states. Mueller (1989:78) reasoned this could not be due to nuclear weapons since it was not confined to the nuclear-armed powers, and concluded, much like Levy who had examined a period ten times longer, that "the conviction has now become widespread that war in the developed world would be intolerably costly, unwise, futile, and debased."

Similarly, Gaddis (1987) discussed how the Cold War had been such an unusual Long Peace between major powers. He joined others in a later book (edited by Kegley, 1991) asking why the Long Postwar Peace was on the verge of becoming the longest period without warfare among the major powers. (The 44 years of great power peace from the end of the Franco-Prussian War in 1870 to 1914 match the 44 years from the end of the Korean War in 1953 to 1997, so the long postwar peace has just now attained record length.) Singer (1991) produced 13 plausible hypotheses to account for the long postwar peace among the major powers, and 
showed that in many ways the data on the amount of war did indicate a decline in war among the more prosperous states.

The end of the Cold War around 1989 further stimulated inquiry into the declining trend in warfare. Some (Singer and Wildavsky, 1993) raised the possibility that we were about to experience a New World Order, or even the end of history (Fukuyama, 1989), in which the ideological differences that bred World War II and the Cold War, the Korean War, the Vietnamese War, and the Russian War in Afghanistan would be gone. Fukuyama foresaw an ensuing liberal peace lasting indefinitely. A virtual cottage industry of empirical studies has developed examining the evidence for the Kantian "democratic" peace. Recent empirical studies of the "democratic peace" include the one by Russett (1997) that found that all the elements alluded to by Kant, namely, joint democracy, shared trade, and membership in the same international organizations, independently contribute to peace between pairs of states; and by Oneal and Russett (1997b) that claimed that democracies are less likely to fight each other than one would expect, even when controlling for the expected utility they would gain from attacking each other. Though the studies of the democratic peace are too numerous to cite herein, they are extensively and sensitively summarized by Maoz (1997), one of the important contributors to the "democratic peace" analyses. The overall perspective of these scholars is reflected by Gurr, Marshall, and Khosla (2001:1) who conclude that we have a "world more peaceful than at any time in the past century."

Although it has almost become commonplace to say that war is becoming obsolete, some cautionary notes have emerged as well. For instance, Gurr, Marshall, and Khosla (2001:Introduction) claimed, "Most regions of the world became more secure in the late 1990s. The turbulence that accompanied the end of the Cold War was largely contained by the end of 2000." Yet they also concede that serious armed violence persists in parts of Africa and Asia. Similarly, Kegley (1991:xi) sounds a congratulatory note in claiming that "the period since 1945 arguably represents the longest period of great power peace since the birth of the modern world system in 1495." Yet he later admits (p. 8) that to speak of a long postwar peace does run the risk of misrepresenting a reality which is in fact a "long war" if one examines the entire system and includes all three types of war that occurred. Similarly, Eberwein and Chojnacki (2001:3) concluded that empirical support for democratic peace is robust irrespective of the specific operationalizations of "democracy" used. However, they also noted that the transition to democracy (especially if it is revolutionary) may be accompanied by a high incidence of international violence. Consequently, they conclude that these findings emphasize the importance of examining domestic conflict as well as inter-state war, in that some types of conflict may lead to an externalization process (2001:3).

\section{Countervailing Trends}

In contrast to the optimism of the "democratic peace" proponents, other scholars perceive an increase in conflict, particularly after the end of the Cold War. From a theoretical perspective, a number of "realists" expect more warfare. Some, such as Mearsheimer (1990), predicted that the amount of war would soon return to more normal levels, and that the world would soon miss the dampening effect of the Cold War. Others, such as Huntington (1993), argued that the ideological conflict of the Cold War would be replaced by "ethnic conflict" along historical cleavage lines-a "clash of civilizations." Similarly, Holsti (1996) has discussed the emergence of new "wars of the third kind" and Kaldor (1999) has highlighted new types of wars based on economic conflict and the activities of paramilitary actors.

A surge in the number of conflicts and wars has been noted in empirical studies as well. Gurr (1994) found that for what he calls "ethno-political conflicts" since 1945, a trend somewhat consistent with Huntington's view was borne out: the number of 
ongoing ethno-political conflicts in the world doubled from the 1950 s to the 1990 s, and by the end of the period Gurr studied (1993-94), 36 of the 50 serious ethnopolitical conflicts were "civilizational" as defined by Huntington. Wallensteen and Axell (1994:1) counted 90 armed conflicts in the period 1989-1993, involving over one-third of the members of the UN. Similarly, the State of War and Peace Atlas of the International Peace Research Institute of Oslo (Smith, 1997:13) indicates that the period 1990-1995 has seen 70 states involved in 93 wars (primarily civil).

Similarly, Brecher and Wilkenfeld (1997:xviii) argue that inter-state turmoil has not abated in the post-Cold War years, since there were 21 full-scale international crises from 1990 to 1994 . They conclude, "As the twentieth century draws to a close, it is timely to look back on an epoch of pervasive turmoil-two world wars, the end of the colonial era, and a large number of crises and conflicts. Notwithstanding the 'long peace' between the two superpowers, the post-World War II international system has been characterized by persistent violence in many regions" (1997:1). In the same vein, Marshall (1999:10) argues that the other side of the "long peace" is the "third world war" in which the pattern of violence has shifted to the periphery and is characterized by civil warfare and ethnic conflict. Yet, despite the longstanding high incidence of civil conflict, such wars have received less empirical scrutiny, partly because data on their potential "correlates" have not been as thoroughly developed. This, of course, creates an imbalance between the scholarly resources deployed to study various types of war and the frequency of such wars now occurring. Until now, the "examination of other gross types of political violence, such as civil war and revolution, have been kept conceptually distinct, under the assumption that domestic forms of political violence are qualitatively different from inter-state varieties (meaning that they are assumed to have causes that are qualitatively distinguished from the causes of inter-state war) as are minor power wars, and even, major-minor power wars" (Marshall, 1999:38). To overcome this imbalance and in order to understand patterns of contemporary warfare, Marshall contends that scholars must "acknowledge all forms of violence and warfare as being essentially related and similarly problematic" (1999:14). Consequently, Marshall, like Snow (1996), Sandole (1999), and Eberwein and Chojnacki (2001), encourages the development of a comprehensive view of violence. He argues that the bifurcations in war studies have become less tenable, and that an overarching view of the nexus between internal and external conflict, and especially warfare, gains saliency as the political borders separating the internal from the external become more permeable (Marshall, 1999:19). The development of an overarching view of war along these lines is one of the primary aims of this present project.

\section{Different Visions of Reality}

As is evident, the conflicting visions of the trends in warfare are partially determined by the type of conflict one is studying. Contradictory trends emerge if one is studying only major power wars, or all inter-state wars, or all civil wars, or conflicts occurring below the war thresholds. However, among empirical analyses, there are also differences that result from the particular data sets utilized. There has been a proliferation of data-gathering projects on armed conflict in recent years. Each project has developed its own foci and definitions of what constitutes armed conflict, and has utilized different criteria by which conflict is divided into subcategories. Unfortunately this proliferation has led to confusion in the discipline, a duplication of efforts, and a situation in which some types of conflict (and some temporal zones) are heavily studied, while others have been ignored or under-studied. The vast majority of these projects have focused exclusively upon conflict within the post-World War II era. (Two notable exceptions to this pattern 
are the Long Range Analysis of War Project led by Claudio Cioffi-Revilla (1990), and Violent Conflicts by Peter Brecke.) Yet, beyond the similarity in time frame, most of these projects examine conflict is such different ways that attempting to compare their findings becomes a frustrating exercise. In his examination of many of these data sets, Brecke (1999:1) has complained that a primary difficulty is that in many projects their classifications of conflict are not clearly specified. He discouragingly concludes, "We possess criteria with which to consistently allocate particular conflicts to only the crudest categories such as inter-state versus civil war. For more discriminating delineations there exist no agreed-upon characteristics to define them other than things like a peasant revolt is one in which peasants are the main group fighting against the authorities."

Eberwein and Chojnacki (2001:8) conducted a comprehensive comparison of several of the data sets on violent conflicts since 1945 and concluded that "the real world is one, but the data on violent conflicts suggest different worlds of violence." In particular, they examined the data produced by CDP (the Conflict Data Project at Uppsala), AKUF (at Hamburg), KOSIMO (at Heidelberg), the State-Failure Project (at Maryland), and the COW (Correlates of War) MID (militarized interstate disputes) and Inter-state and Civil war data sets. They limited their analysis to the post-World War II era to focus upon the common time frames among these projects, and they disaggregated the sectors of the projects that dealt with interstate versus intra-state conflict, and warfare versus sub-war levels of conflict. Though they expected the highest levels of convergence among the data sets concerning inter-state wars, the differences were fairly significant, reflecting different events, different start dates, and different intensity levels. Though a number of differences in the data were relatively minor (differences in starting dates), a significant number were associated with the differences between the quantitative definitions utilized by COW and CDP versus the qualitative approaches utilized by AKUF and KOSIMO. From our perspective, their findings also revealed some of the drawbacks of the approaches taken by other data projects. For instance, Eberwein and Chojnacki (2001:12) noted that it was not fully clear why a "contested incompatibility" over government or territory needed to be part of the definition of conflict, as is done by the CDP (leading to the elimination of a number of wars included by COW whose issue is indeterminate). The qualitative definitions of armed conflict utilized by AKUF and KOSIMO lead to different interpretations of specific events and unreproducible coding criteria (Eberwein and Chojnacki, 2001:13). For lower levels of violence, the State Failure Project data set appeared to be less comprehensive than the other data sets included. Consequently, each of the data sets captures only a particular segment of violence (Eberwein and Chojnacki, 2001:27). Yet many of the users of these data sets are not familiar with the detailed coding rules and the theoretical assumptions underlying these data sets.

Similarly, Sarkees and Singer (2001) briefly examined and compared the coding rules for fifteen of the data sets on violent conflict and came away with the same impression of multiple parallax views. In contrast to COW, the major weakness of these projects is their limited scope, in terms of both types of conflict and time period examined. Though there seems to be a decreasing focus only upon major power war, the most obvious commonality among the other data sets is the focus upon conflict in the post-World War II era (in 11 out of 15 data sets). Consequently, many of the visions of the peacefulness of the system are predicted only upon an analysis of the trends established within a 50-year time span. Though from an optimistic perspective, having comparable time spans should facilitate the exchange of information among scholars and lead to rich and fully documented data sets, this propensity is also troubling. A number of these projects justify their focus upon events since 1945 by arguing for the distinctiveness of this period: that contemporary conflict is different in kind from prior conflict. Yet the lack of 
comparable data from other eras makes the a priori assertion questionable. Indeed, despite the rich speculative essays as well as the multivariate studies of the Kantian and non-Kantian influences on resort to force-all written in the context of an assumed spread of democracy and decline in war in the post-World War II era, little data-based research has examined trends in war overall and over longer time periods. One useful exception, Levy, Walker, and Edwards (2001), examined data on war over a long period, with special attention to 1816-1995. Similarly the studies of lower levels of conflict generally limit themselves to the period since World War II, often to ensure the availability of data on all relevant control variables.

A second commonality among many of these data sets is the primary focus given to inter-state conflicts. This proclivity replicates practices among earlier international politics scholars and, in our opinion, has thus led to a dearth of knowledge about alternative forms of conflict. The tendency has been somewhat offset recently by the increasing interest in intra-state (defined primarily as civil) wars, yet it leaves the categories of extra-state and inter-communal conflicts largely unexplored. Three of the major projects that have attempted a broader approach are CDP (the Conflict Data Project at Uppsala), CSP (the Center for Systemic Peace, Major Episodes of Political Violence project at Maryland), and the MAC (Holsti's Major Armed Conflict project). One issue with which these studies have grappled is the appropriate level(s) of violent conflict to study. COW has principally concentrated on war and has set the 1,000 fatality threshold for the war classification, while including lower levels of violence in the MID (militarized inter-state disputes) data set. CDP and CSP in particular incorporate a number of levels of violence in their overall data. Combining the various violence levels into one data set enables scholars to examine the relationship between levels of violence and to look at the issue of violence escalation, particularly for CDP, this type of approach has some associated side effects. For instance, CDP's desire to examine levels of violence on a calendar year basis leads to the different classifications and different start dates for a number of wars between COW and CDP. If there are 300 fatalities per month from November to February, CDP would code an intermediate conflict the first year (becoming a war only in the second year), whereas it would be considered a war for the entire period under COW criteria. There are two additional characteristics of a number of these data-gathering projects that are more troubling. One is the lack of strict coding rules or criteria. Several of the projects (like Brogan, 1998; and Bercovitch and Jackson, 1997) provide detailed case studies, yet have limited or flexible coding criteria. Other projects base their categorization criteria upon characteristics that require significant personal interpretation, or upon rules that the authors admit to bending to allow the inclusion of interesting cases (Holsti, 1996). It is also sometimes difficult to discern why certain conflicts are disaggregated (like the 1967 Arab Israeli war in CDP) and others not. Such propensities make the replication and comparison of findings more difficult. A related issue is the practice of some projects to base their entire categorization of conflict upon factors that are difficult to evaluate and/or whose significance may change over time. For instance, in the data on "ethnic" wars (Scherrer, 1999), it is often difficult to determine whether ethnicity is the dominant motivating factor for the combatants, whether the importance given to ethnicity is a constant or varies over time, and whether "ethnic wars" can be a mutually exclusive category as distinct from religion or ideology. In evaluating much of the "ethnic conflict" literature, Lake and Rothchild came to a similar conclusion: "The most widely discussed explanations of ethnic conflict are, at best, incomplete and, at worst, simply wrong. Ethnic conflict is not caused directly by inter-group differences, 'ancient hatreds' and centuries-old feuds, or the stresses of modern life within a global economy. Nor were ethnic passions, long bottled up by repressive communist regimes, simply uncorked by the end of the Cold War" (1997:97). 
The necessity for such value judgments in alternative categorizations has reinforced the decision by the COW Project that a useful and encompassing typology of armed conflict can be developed based upon the political status of the protagonists and upon a clear delineation between war and lower levels of violence. Such a schema allows for the creation of mutually exclusive categories, and creates options for the inclusion of "new" types of conflict or actors. The COW framework has a relatively extensive time span, and includes all three major types of war, so that it is a suitable perspective from which to develop a more comprehensive view of war.

\section{A Comprehensive View}

A view of warfare cannot be based upon examining one type of war alone. Interstate and intra-state wars are each part of the picture. Holsti (1997:5) has argued that the field of international politics may have limited relevance unless it can move to the broader problematique facing the contemporary third world, since the problem of inter-state war is not the critical issue facing the less-developed nations. Yet interstate and civil wars are linked in many ways, as are domestic and foreign policies in general. For instance, though some argue that "democratic" states may have less conflict between/among themselves, it is unclear whether "democracies" are less likely to engage in conflict with other entities or to interfere in the internal conflicts of others. Yet such questions cannot begin to be addressed without data that encompasses a broad spectrum of wars, including inter-state, extra-state, and civil wars.

Initially, we are concerned that a broader understanding of war has been hampered by the common failure to examine extra-state wars. The difference between inter-state and extra-state wars is fundamentally a matter of diplomatic recognition; the Opium Wars, for example, are classified as extra-state simply because China was not at the time diplomatically recognized by England and France. Cognizant of the underlying similarity obscured by this legal distinction, Singer and Small $(1972,1982)$ had originally designated inter-state and extrasystemic wars as the two types of "international" war. Yet subsequent research did not follow this path, focusing only upon inter-state wars. Extra-state wars merit study not just for their frequency, but also for their intrinsic importance. Accounting for almost three million fatalities since 1816, these wars have been associated with one of the most important cyclical transformations of the modern international system-first the spread of imperialism, and then the emergence of independent new nations. It is plausible that models designed to explain inter-state war will be applicable to some extra-state wars as well, and that perhaps even a general model accounting for international war will eventually emerge. On the other hand, if stateless societies act in ways that are fundamentally different, or if decisions for war are different when one side is much more powerful than the other (Vasquez, 1993), then extra-state wars may be significantly different in their etiology than inter-state wars between two major powers. Admittedly, the scientific study of extra-state wars has been hampered by a significant problem concerning the data on war deaths. In the case of many imperial wars, the Europeans who kept the records did not do as thorough a job of reckoning (not to mention preventing) the number of non-European dead, making it more difficult to determine the severity of their imperial conflicts. However, recent archival work has been instrumental in assisting data-gathering, and (as is evidenced by recent findings about the Boer War) future improvements in counting the colonial as well as imperial dead would more accurately reflect the true destructiveness of these extrastate conflicts.

Furthermore, a comprehensive examination of war is needed because we see the potential for further increases in both civil and extra-state wars. Since the 
withdrawal of the Soviet Union from armed rivalry with the West, a number of tendencies already on the horizon have picked up momentum and have furthered the disaggregation of the more conventional state-based affiliations in the global system. The old order is being seen as less able to meet the needs of large segments of the global population. Consequently, trends that have been evident for at least the past thirty years have signaled the growing importance in international interactions of other sub- (or intra-) and extra-national entities alongside the territorial state (Singer, 1969:23). It could be argued that the Cold War both hindered and hastened these processes. On the one hand, the Cold War delayed the more natural tendency toward increasing the number of effective multinational actors; without such a rigid worldwide bifurcation, regional and global institutions could have begun to more effectively address some of the increasingly important problems emerging from economic dislocation, environmental deterioration, the weapons trade, crime, drugs, and disease. On the other hand, in the absence of effective international institutions, not only have many of these problems continued to fester, they have also led to the emergence of new actors and new types of conflict. It could even be argued that the efforts of the superpowers during the Cold War to mobilize their own populations (as well as those of other states) encouraged certain countervailing tendencies. The superpower interventions in the domestic politics of allied and third world nations alike may have persuaded other actors to test their own efficacy. It is anticipated that the flourishing of such non-state actors has been (and will continue to be) generated, inter alia, by: the increase in the worldwide arms trade, regions with diminishing resources and economic opportunities, and the increasing power of MNCs (multinational corporations) and their drive to secure resources, markets, and investment opportunities (increasingly with private armed forces). These conditions have contributed to the increasing number of non-state actors with the motivation and the capacity to engage in armed conflict both within and between traditional states. The variety of groups involved in contemporary "civil wars" and the activities of para-military and "terrorist" groups are forerunners of actors that may soon be willing and able to inflict and sustain casualties severe enough to qualify as wars. Thus not only is it the IGOs (inter-governmental organizations) and MNCs that enjoy greater latitude, there is also evidence of the emergence of failed states, or "quasi-legitimate" states, and regimes with de facto independence, yet which are not members of the international system, that have the potential to engage in warfare. The current "war against terrorism" (or against Al Qaeda or the Taliban) represents several of these trends. Before Sept. 11th, 2001, there was an intra-state war in Afghanistan in the 1990s, between the Taliban and the Northern Alliance. In this fighting, the Taliban ousted the Northern Alliance from the capital and all but a tenth of the Afghan territory, but the Northern Alliance still held the UN seat. With control of the capital and territory, more important criteria to COW than diplomatic recognition, the Taliban became the rulers of the Afghan state. After Sept. 11th, around mid-October, the U.S. intervened, and there was an inter-state war, with the U.S. and its allies attacking the Taliban government of Afghanistan, and succeeding in ousting the Taliban from power. Meanwhile, the U.S. and its allies are engaged in armed combat against an extra-state actor, Al Qaeda, not only in Afghanistan but also in Pakistan and perhaps other countries. But it remains to be clarified whether this will attain the sustained combat involving substantial battle deaths to be coded as an extra-state war. The growing influence of similar new international actors may lead to different types and patterns of warfare. Given the transitory state of the global system, the more familiar types of conflict will not disappear, but they will be augmented and perhaps their foci will shift. Consequently, if we are to understand the future prospects for war, it is necessary to have a typology of war that can deal with the post-Congress of Vienna epoch as well as the post-Cold War era, and that will allow us to examine 
war's evolution in all its three major forms. Consequently, we are convinced that not only is a comprehensive analysis of war needed, but, at this moment, the COW warsets offer the most extensive data and for the longest period to begin this process.

\section{Classifying Modern Wars}

To understand any phenomenon, we must first be able to describe it, and this may be particularly true of war, because not only does it take an elusive variety of forms in any given historical period, but these forms also change across time. In 1994 the Correlates of War Project began to reconsider the classification of wars as they originally appeared in The Wages of War, 1816-1965: A Statistical Handbook (Singer and Small, 1972) and Resort to Arms: International and Civil War, 1816-1980 (Small and Singer, 1982). The motivation was to expand the war typology to address certain types of armed conflict not previously included; and to clarify the coding rules that had created some ambiguity in the war classifications. A brief summary of these changes is provided here, but the reader may wish to consult Sarkees (2000) for a more complete discussion of the coding rules and a listing of the inter-state, extra-state, and intra-state civil wars. The data were updated through 1997, and the variable layouts were also modified to provide more information (particularly about battle deaths) and to allow for easier analysis of all three types of war. ${ }^{1}$

\section{Initial Classification}

War has been defined by the Correlates of War Project as sustained combat between/ among military contingents involving substantial casualties (with the criterion being a minimum of 1,000 battle deaths). The requirement of sustained combat eliminated massacres from the classification of wars. Wars were subdivided into three categories based upon the political status of the combatants, primarily whether they were or were not members of the modern inter-state system (from 1816 to the present). To be considered a system member, a state had to have a population of 500,000, to be independent, and to have been recognized (by Britain and France, the League of Nations, or the United Nations) (Small and Singer, 1982:38-43). The original COW war categorization included: (1) inter-state wars, fought between two or more state members of the inter-state system; (2) civil wars, fought within the "metropole" of a member state of the system by forces of the regime against an insurgent group; and (3) extra-systemic wars, fought between a member of the inter-state system and a territorial and political entity not recognized as a part of that system. Inter-state wars also had to have a total of at least 1,000 battle deaths, while extra-systemic and civil wars required an annual average of 1,000 battle deaths as a measure of sustained hostilities. ${ }^{2}$ One of the difficulties with this typology was the importance of the "metropole" distinction for civil wars. The metropole referred to areas integrated under the central government, whereas nonintegrated areas (the periphery) faced restrictive governmental provisions (Small and Singer, 1982:211-212). Civil wars involved significant military action that occurred between political entities within the boundaries of the metropole. Wars against territories not politically integrated into the metropole (even if they were within the territorial boundaries of the state) were considered extra-systemic. Thus

\footnotetext{
${ }^{1}$ One version of these data sets is available on the website of the Peace Science Society: http://pss.la.psu.edu.

${ }^{2}$ See Vasquez, 1993:15-29 for a critique of the original COW war typology.
} 
extra-systemic wars could take place within or outside the territorial boundaries of the state. The extent to which this distinction seemed in conflict with the COW state-centered focus in its other data sets became one of the primary motivations behind the revised typology. Furthermore, the initial classification of extra-systemic wars was creating anomalies, by which disparate cases were grouped together, or conversely allowing essentially similar wars to be placed in different classifications (for instance, the Greek Civil War was classified as extra-systemic, unlike the U.S. Civil War, which was classified as a civil war).

\section{The Expanded Typology}

To make the current war data more consistent with the original COW statecentered focus, the major alteration in the war typologies was a change in the definitions of extra-systemic (now extra-state) and civil (now within intra-state wars). Intra-state wars are now those between or among two or more groups within the internationally recognized territory of the state. They include civil wars (involving the state government and a non-state actor) and inter-communal conflicts (involving two or more groups, none of which is the state government). Extra-state wars involve war between a territorial state and a nonsovereign entity outside the borders of the state. This alteration in terminology and criteria has resulted in the re-classification of a number of formerly extra-systemic wars as civil wars (including the Greek Civil War, the Texan War, and the Ogaden). ${ }^{3}$ The revisions also included a subdivision of civil wars into (a) wars for control of the central government, and (b) wars over local issues, including secession. This distinction highlights how many civil wars are fought not to change the composition or the form of government in the capital, but to gain greater regional autonomy, if not outright independence. Further, though the focus of the project has been, and continues to be, upon the territorial state, considerations concerning future trends in warfare (plus the fact that there were a growing number of wars and armed combatants that did not fit precisely within the existing COW categories) led to the creation of a new sub-classification of wars that involve war between non-state actors, now called inter-communal within the intra-state war category. ${ }^{4}$ Since our focus here is wars involving states, inter-communal wars will not be included in the following analysis. ${ }^{5}$

\footnotetext{
${ }^{3}$ In effect, the set of extra-systemic wars was partitioned into two subsets. The first, and smaller subset consisted of extra-systemic wars that took place within the recognized territory of the state, and thus are being assigned to the civil war category. The remaining, and much larger subset consists of the vast bulk of the imperial and colonial wars, which occurred beyond the recognized boundaries of the system member. These remaining wars are now called "extra-state." Extra-state wars are those in which at least one major participant in the conflict is a member of the state system, and is involved in conflict against troops (however irregular and disorganized) of an entity that is not a member of the state system.

${ }^{4}$ To complete the theoretical framework, another category is possible, that involving conflict between two nonstate actors. To fall into this classification, conflict would have to take place across the boundaries of a territorial state. Though it could take many forms, an obvious example of this type of warfare might be a conflict involving multinational corporations. A precursor to this trend might be the recent hiring by British Petroleum of an army to combat the guerillas in Colombia (Shemo, 1996). Since we have no immediate plans to develop a data set on this type of conflict, we have omitted it from our current schema.

${ }^{5}$ Inter-communal wars between nongovernment forces within a state are obviously not new, though we see them as increasing in frequency since advanced weapons technology boosts the probability of conflicts realizing the requisite battle death threshold for war consideration. Such wars could take many forms, including, for example, conflict between or among "ethnic" or ideological groups. (One thinks of the two Kurdish groups fighting each other in 1996 in Iraq, or the warlord armies in China in the 1920s.)
} 


\section{Summary of the Correlates of War Project's Two Typologies of War}

\begin{tabular}{ll}
\hline \multicolumn{1}{c}{ Traditional Typology } & Expanded Typology \\
\hline I. International Wars & I. Inter-State Wars \\
A. Inter-State Wars & \\
$\begin{array}{ll}\text { B. Extra-Systemic Wars } & \text { II. Extra-State Wars } \\
\text { 1. Imperial } & \text { A. State vs. Independent Non-State Actor } \\
\text { 2. Colonial } & \text { B. State vs. Dependent Non-State Actor } \\
\text { II. Civil Wars } & \text { III. Intra-State Wars } \\
& \text { A. Civil Wars } \\
& \text { 1. For central control } \\
& \text { 2. For local issues } \\
& \text { B. Inter-Communal Wars (not included in this } \\
& \text { analysis) }\end{array}$ \\
\end{tabular}

Source: Sarkees, 2000.

The update also added new wars to each of the war categories, so that for the period of 1816 to 1997 there are now 79 inter-state wars, 108 extra-state wars, and 214 civil wars in the data sets. The update also incorporated more data on fatalities, as the initial COW warsets had included information only on the battle deaths of the system member, which thus lessened the apparent severity of extrastate and civil wars. Over the years, heroic attempts have been made to augment these figures with fatality figures for the non-state war participants, and the data here reflect the results of some of these efforts. We recognize that additional work is needed to improve the accuracy of these battle-connected fatalities, but are relatively comfortable in using them in the "total death" figures presented here.

\section{Trends in Modern War}

In attempting to develop a comprehensive analysis of the incidence of war, we wanted to examine the trends in war revealed by combining all three types of war, and to focus upon the interplay among them. This global look presents a mixed pattern, discouraging easy optimism vis-à-vis any type of war (see Table 1). In the 180 years from 1816 to 1997 , there have been 79 inter-state wars, 214 civil wars, and 108 extra-state wars, for a grand total of 401 wars. (For comparison, the data for the first and last decades were normalized as if covering a full 10-year period, which yields the grand total figure of 412.) This is an average of almost 22 wars of all types per decade. There have been more wars in the twentieth century than in the nineteenth century, and about half these wars can be designated "international," by which we mean that they are either inter-state or extra-state wars. Interstate wars have averaged over 4 per decade, and extra-state wars, most of which were part of empire-building, have been more common, averaging almost 6 per decade up to the recent past, leading to a combined average of 10 "international" wars per decade. But, as evident from Table 1, extra-state wars virtually disappeared at the end of the twentieth century due to the increase in the number of sovereign and independent state members, and the corresponding decline in colonies and dependencies (though as argued earlier there appears to be a potential revival of this type of war). Meanwhile, civil wars have occurred at an average rate of over 11 per decade.

From the point of view of global security, it is a shocking fact (as seen in the last column of Table 1) that in some ways we are living through one of the worst decades in modern history. The 1970s were the decade with the most war onsets of all types. This was not an isolated spike, as the 1960s and 1980s were also worse 
TABLE 1. War Onsets per Decade, 1816-1997

\begin{tabular}{|c|c|c|c|c|c|}
\hline Decade & $\begin{array}{c}\text { Inter-State } \\
\text { Wars }\end{array}$ & $\begin{array}{c}\text { Extra-State } \\
\text { Wars }\end{array}$ & $\begin{array}{c}\text { Subtotal for } \\
\text { International } \\
\text { Wars }\end{array}$ & $\begin{array}{l}\text { Civil } \\
\text { Wars }\end{array}$ & $\begin{array}{c}\text { Grand } \\
\text { Total }^{*}\end{array}$ \\
\hline 1816-1819* & 0 & 2 & 2 & 1 & 8 \\
\hline $1820-1829$ & 2 & 6 & 8 & 7 & 15 \\
\hline 1830-1839 & 0 & 5 & 5 & 11 & 16 \\
\hline $1840-1849$ & 4 & 8 & 12 & 9 & 21 \\
\hline $1850-1859$ & 5 & 9 & 14 & 8 & 22 \\
\hline 1860-1869 & 8 & 5 & 13 & 14 & 27 \\
\hline $1870-1879$ & 4 & 10 & 14 & 9 & 23 \\
\hline 1880-1889 & 3 & 12 & 15 & 3 & 18 \\
\hline 1890-1899 & 4 & 16 & 20 & 9 & 29 \\
\hline 19th Century & 30 & 73 & 103 & 71 & 179 \\
\hline 1900-1909 & 6 & 4 & 10 & 7 & 17 \\
\hline 1910-1919 & 8 & 6 & 14 & 11 & 25 \\
\hline 1920-1929 & 2 & 6 & 8 & 12 & 20 \\
\hline 1930-1939 & 9 & 2 & 11 & 8 & 19 \\
\hline 1940-1949 & 3 & 5 & 8 & 9 & 17 \\
\hline $1950-1959$ & 3 & 6 & 9 & 11 & 20 \\
\hline 1960-1969 & 6 & 3 & 9 & 16 & 25 \\
\hline 1970-1979 & 7 & 3 & 10 & 26 & 36 \\
\hline 1980-1989 & 4 & 0 & 4 & 19 & 23 \\
\hline 1990-1997* & 1 & 0 & 1 & 24 & 31 \\
\hline 20th Century & 49 & 35 & 84 & 143 & 233 \\
\hline Totals & 79 & 108 & 187 & 214 & 412 \\
\hline
\end{tabular}

*Total figures for 1819 and 1997 have been normalized to ten years for comparison purposes. The Grand Total uses the normalized figures.

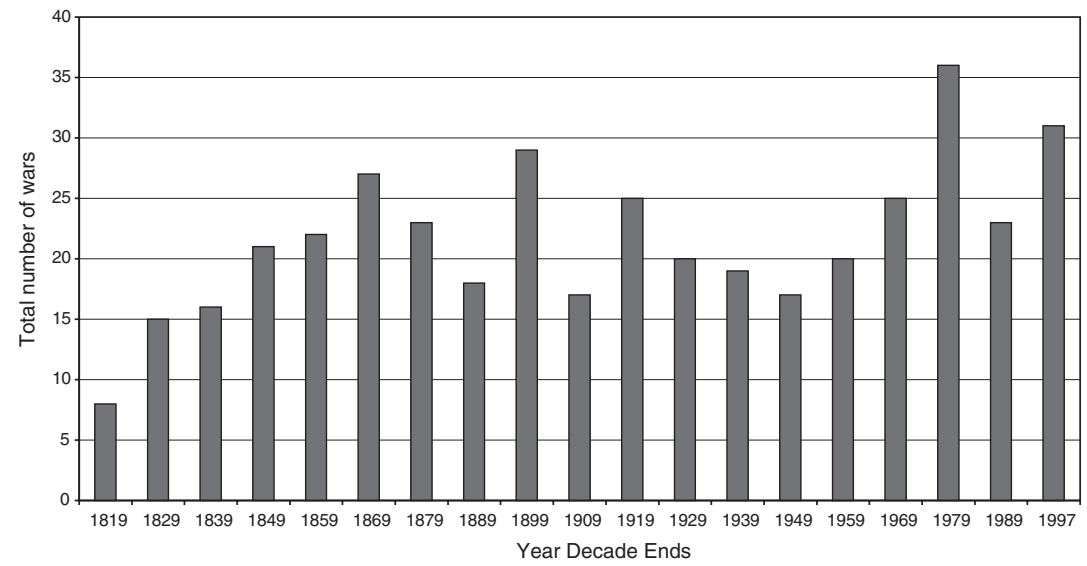

FIG. 1. Total Number of War Onsets per Decade (1819 and 1997 data normalized for 10 years)

decades than average. And while the data for the 1990s are not complete, the 1990s will likely win the dubious distinction of being one of the two most war-prone decades since the Congress of Vienna. (See Figure 1.)

Though inter-state wars do appear to have declined in the 1990s, inter-state wars do not appear to be on a sustained decline (even in the post-World War II era). The 


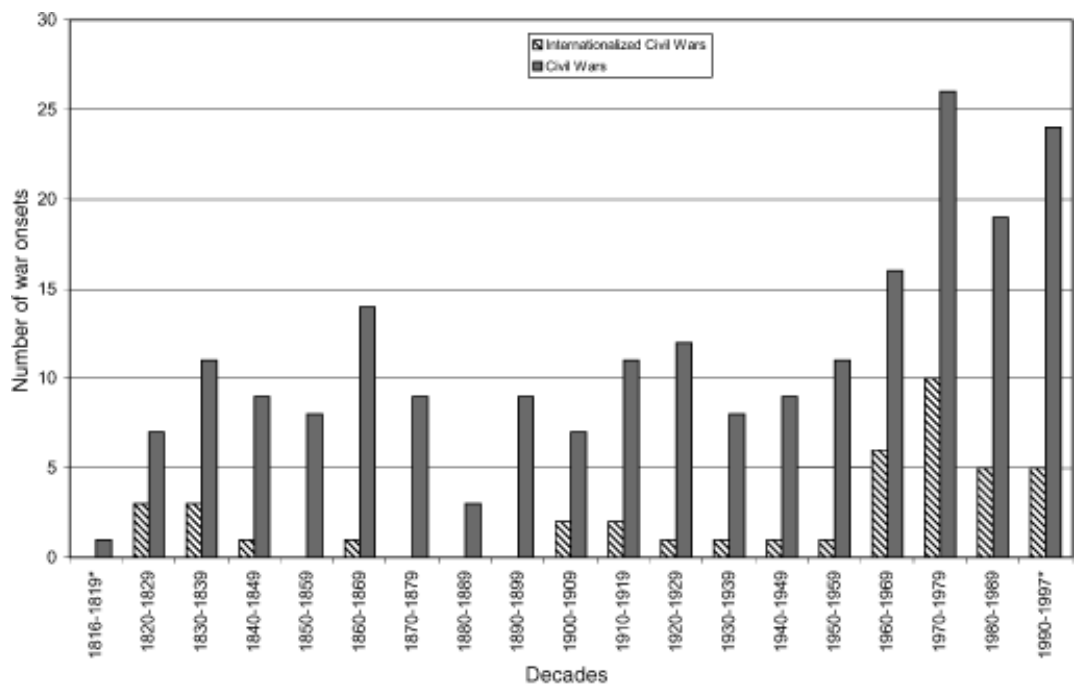

FIG. 2. Internationalized Civil Wars Compared to All Civil Wars

decades with the most inter-state war onsets have been widely scattered: the $1850 \mathrm{~s}$, the $1910 \mathrm{~s}$, the $1930 \mathrm{~s}$, and the 1970s. As other scholars have speculated, these data indicate a cyclical pattern rather than a strong declining trend. Furthermore, the decades from the 1960 s to the 1980 s have seen an average $(n=4)$ to an above average amount of inter-state war.

Extra-state wars peaked in the 1870-1899 era. Largely because of these imperial wars against non-state actors, the 1890s were (until the 1990s) the second most warprone decade, second only to the 1970s. Ironically, analysts in Europe, the source of much of this nineteenth-century imperial savagery, were writing then about the unprecedented era of peace from 1870 to 1914. Perhaps then, as in our time, the scholars were optimistic about peace because war had been displaced away from the rich and into the poor nations.

The main reason for the recent surge in overall amounts of war is that civil wars are breaking out at an all-time record rate. However, in addition to the significant increase in civil wars since the 1960 s, the data also reveal the increasingly international component of civil wars. In particular, there has been a marked increase in the number of civil wars that are internationalized civil wars (involving interventions by outside system members). (See Figure 2.)

Overall, between 1816 and 1997, of the 214 civil wars, only 42, or 19.6 percent, were "internationalized" by the intervention of outside states. Whereas in the period prior to 1960 , only 12.4 percent of the 129 civil wars were internationalized; this rose to 30.6 percent of the 85 civil wars in the post-1960 era. Consequently, a comprehensive view of international war activity would include inter-state, extrastate, and internationalized civil wars. Though the trends for this overarching international war category (shown in Figure 3) do show a general decline in the onset of war in the post-World War II era, the past 50 years do not appear to be overwhelmingly peaceful. The number of war onsets for the 1980s and 1990s are below the median of 12 for the entire period, yet they are close to the median for the postwar era.

While the total number of war onsets per decade has been increasing, so has the number of members of the inter-state system, which had grown from 23 members in 1816 to 181 members by 1995. Since the number of wars has not grown as fast as the number of system members, the average number of wars per state-system 


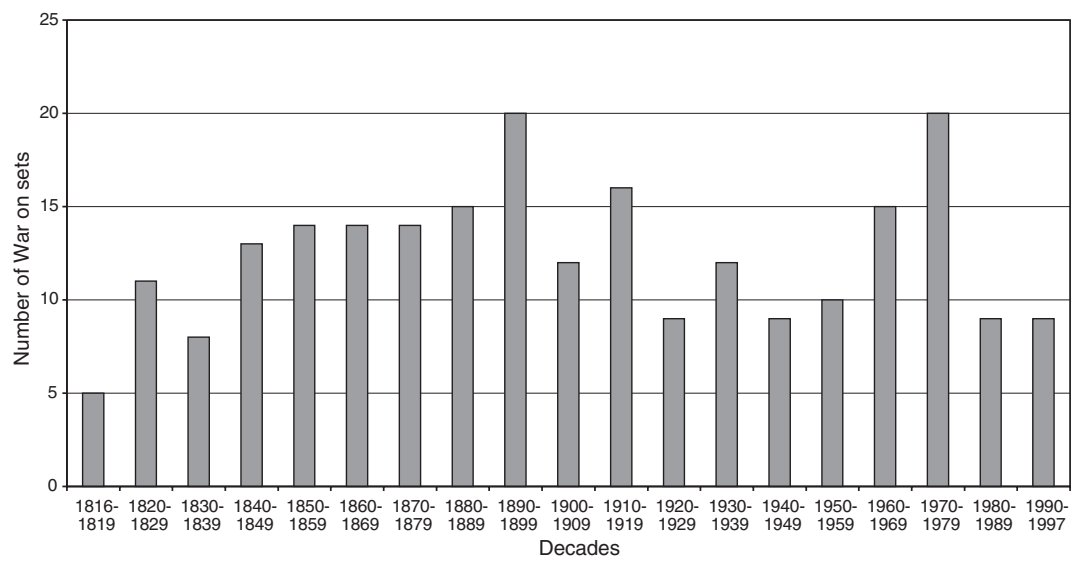

FIG. 3. Total International and Internationalized Civil Wars (first and last decades reflect normalized data)

TABle 2. War Onsets per System Member per Decade

\begin{tabular}{lccc}
\hline & $\begin{array}{c}\text { Total Number } \\
\text { of Inter-State, } \\
\text { Extra-State, and } \\
\text { Civil Wars }\end{array}$ & $\begin{array}{c}\text { Number of } \\
\text { System Members } \\
\text { per Mid-Decade }\end{array}$ & $\begin{array}{c}\text { Wars per System } \\
\text { Member }\end{array}$ \\
\hline $1816-19 *$ & 8 & 23 & 0.348 \\
$1820-29$ & 15 & 24 & 0.625 \\
$1830-39$ & 16 & 29 & 0.552 \\
$1840-49$ & 21 & 36 & 0.583 \\
$1850-59$ & 22 & 43 & 0.512 \\
$1860-69$ & 27 & 41 & 0.659 \\
$1870-79$ & 23 & 34 & 0.676 \\
$1880-89$ & 18 & 39 & 0.500 \\
$1890-99$ & 29 & 44 & 0.744 \\
$1900-09$ & 17 & 44 & 0.386 \\
$1920-19$ & 25 & 62 & 0.568 \\
$1930-39$ & 20 & 66 & 0.323 \\
$1940-49$ & 64 & 0.288 \\
$1950-59$ & 19 & 84 & 0.266 \\
$1960-69$ & 17 & 124 & 0.238 \\
$1970-79$ & 20 & 150 & 0.202 \\
$1980-89$ & 25 & 161 & 0.240 \\
\hline 9 & 36 & 181 & 0.143 \\
\hline
\end{tabular}

*The figures for total wars were normalized for a ten-year period for comparison purposes.

member has declined from a peak of 0.744 war onsets per system member in 1890 1899 to about 0.143 in the 1980 s and 0.171 in the latest decade. (See Table 2 and Figure 4.)

This finding reinforces the conclusions of those who focus on the major powers as the primary source of war (since the major powers constituted a greater percentage of the nineteenth-century system). Yet this trend is complicated by the declining frequency of extra-state wars. In analyzing extra-state war, the normalization for state system size makes less sense, since this decline in extra-state wars is of course related to the number of system members. The growth in system 


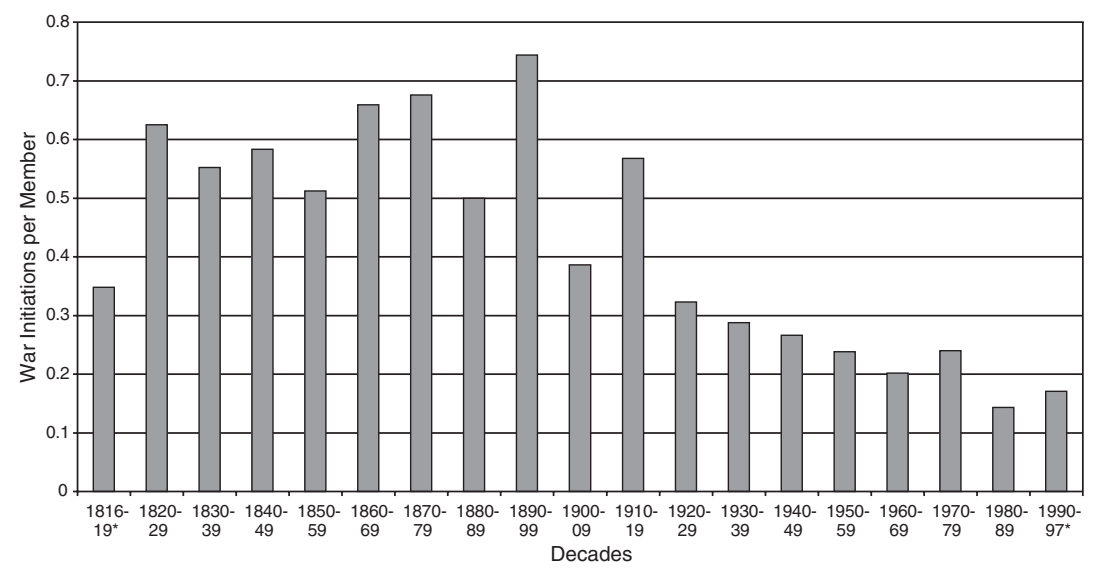

FIG. 4. Number of War Onsets per System Member per Decade (1816-19 and 1990-97 data normalized for 10 years)

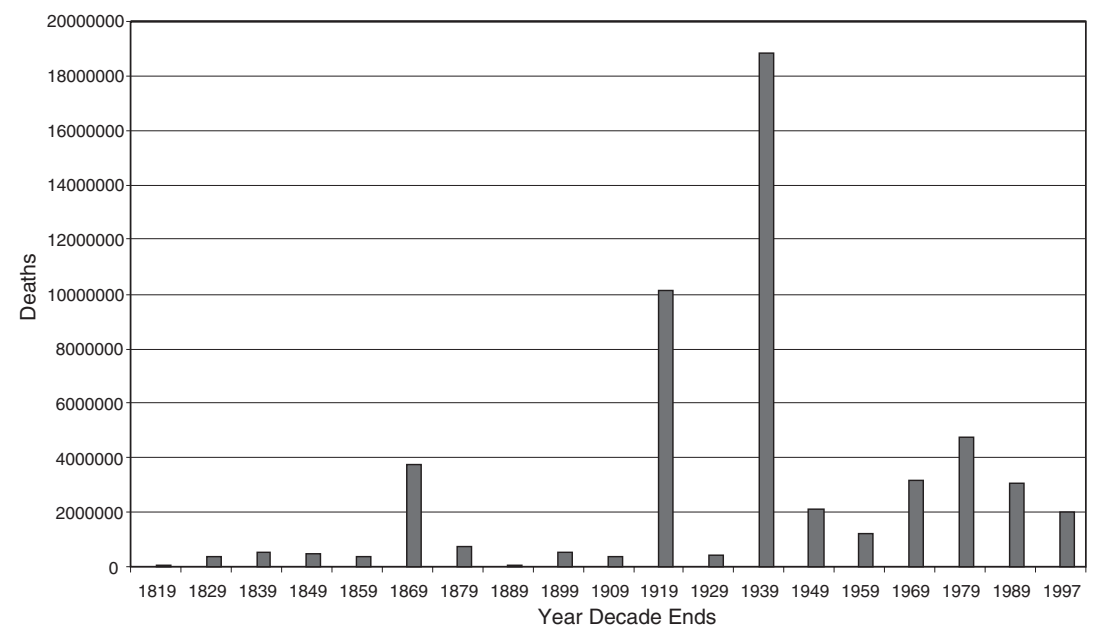

FIG. 5. Total War Deaths per Decade (deaths reported by year in which war began; data for 1819 and 1997 normalized for ten years)

membership was partially a result of successful extra-state wars leading to independence. Conversely, the growth in system membership contributes to a declining potential for extra-state wars by reducing the extra-state territory and population base that could mount a war against a system member.

Some will take comfort in the observation that the overall surge in the number of war onsets can be blamed mostly on the growth of civil wars, and that the danger of inter-state and extra-state war has declined in the past decade. Yet, as Table 3 and Figure 5 demonstrate, that does not necessarily mean that war has become less deadly. The highest fatality periods were clustered around World Wars I and II, yet the "peaceful" post-World War II decades have reported total battle deaths that generally equal or exceed the average over the entire two centuries. Wars begun in the 1970 s were particularly deadly, with 4.75 million fatalities. In fact, over two million battle deaths have occurred worldwide in nearly every decade since World War II. Prior to World War I, only one decade-the 1860s, with the American Civil War and the Taiping Rebellion-produced such carnage, with 3.77 million battle-connected deaths; indeed, in the nineteenth century, no other decade exceeded a million war deaths. 
TABLE 3. Total War Deaths by Decade-Date of War Onset

(For extra-state and civil wars, war deaths are battle related deaths for both the state and non-state participants)

\begin{tabular}{|c|c|c|c|c|}
\hline Decade & Inter-State Wars & Extra-State Wars & Civil Wars & Total War Deaths* \\
\hline 1816-1819* & - & 15,000 & 11,000 & 65,000 \\
\hline $1820-1829$ & 131,000 & 70,500 & 180,100 & 381,600 \\
\hline 1830-1839 & - & 351,000 & 221,939 & 572,939 \\
\hline 1840-1849 & 35,410 & 35,000 & 424,249 & 494,659 \\
\hline $1850-1859$ & 300,000 & 52,000 & 51,400 & 403,400 \\
\hline 1860-1869 & 382,600 & 231,075 & $3,153,625$ & $3,767,300$ \\
\hline 1870-1879 & 507,313 & 116,000 & 135,400 & 758,713 \\
\hline 1880-1889 & 15,332 & 70,500 & 5,000 & 90,832 \\
\hline 1890-1899 & 21,685 & 432,424 & 120,500 & 574,609 \\
\hline 1900-1909 & 170,834 & 236,000 & 11,350 & 418,184 \\
\hline 1910-1919 & $8,941,531$ & 9,102 & $1,192,650$ & $10,143,283$ \\
\hline 1920-1929 & 4,200 & 97,474 & 325,200 & 426,874 \\
\hline 1930-1939 & $17,914,294$ & 12,849 & 914,635 & $18,841,778$ \\
\hline 1940-1949 & 11,400 & 625,000 & $1,477,535$ & $2,113,935$ \\
\hline 1950-1959 & 917,056 & 150,000 & 158,900 & $1,225,956$ \\
\hline 1960-1969 & $1,057,224$ & 100,000 & $2,004,113$ & $3,161,337$ \\
\hline 1970-1979 & 66,901 & 106,000 & $4,581,750$ & $4,754,651$ \\
\hline 1980-1989 & $1,256,145$ & - & $1,789,232$ & $3,045,377$ \\
\hline $1990-1997 *$ & 26,343 & - & $1,568,500$ & $1,993,554$ \\
\hline Totals & $31,759,268$ & $2,709,924$ & $18,327,078$ & $53,233,981$ \\
\hline
\end{tabular}

*Total figures for 1816-1819 and 1990-1997 have been normalized to ten years for comparison purposes. The Total War Deaths uses the normalized figures.

We record a total of over 53 million combat fatalities from 1816 to 1997 . This horrific total is primarily due to inter-state war, in which nearly 32 million military personnel were killed in combat. Civil war combat has been half as deadly, with approximately 18 million combat-related fatalities. Even with our recent effort to count non-system member combat fatalities in extra-state war, extra-state wars remain last in combat "body count," with 2,709,924 fatalities.

Of course, wars are more deadly in the twentieth century than in the nineteenth century. Yet the increase in fatalities is also related to the growth of the total population of system members. Therefore, we normalized battle deaths by controlling for the total population of system members. (See Table 4.) It is interesting to note (also see Figure 6) that the trend in battle-deaths per thousand population is generally relatively flat, with peaks in the $1860 \mathrm{~s}, 1910 \mathrm{~s}$ (WWI), and 1930s (WWII), and only moderate fluctuations at other times. Reflecting this, the correlation between deaths per thousand and the passage of time is an insignificant .031 (Pearson's correlation 2-tailed). The figure for 1960-1969 of .967 deaths per thousand represents the median for the entire period.

The relatively flat rate may say something discouraging about the constancy of warfare in human affairs. With the risk of death in battle trending neither up nor down since the date of Napoleon's exile, we are left to ponder the implications of these findings for future work on a subject that may not be going away as fast as we would wish or might have thought.

This constancy in the incidence of war is also supported by another indicator of trends, derived from correlating the war onsets with time. The correlation between time and the onset of all types of war is 418 (Pearson's correlation 2-tailed, not significant). The relationship between the onset of inter-state war and the passage of 
TABle 4. Decade War Deaths per Thousand Population (for wars beginning during the decade)

\begin{tabular}{lrrrr}
\hline Decade & & & Population of System & Deaths per Thousand \\
Total War Deaths & Midyear & Members (in thousands) & Populion \\
\hline $1816-19 *$ & 65,000 & 1817 & 225905 & 0.288 \\
$1820-29$ & 381,600 & 1825 & 246132 & 1.550 \\
$1830-39$ & 572,939 & 1835 & 285477 & 2.007 \\
$1840-49$ & 494,659 & 1845 & 319659 & 1.547 \\
$1850-59$ & 403,400 & 1855 & 355062 & 1.136 \\
$1860-69$ & $3,767,300$ & 1865 & 780612 & 4.826 \\
$1870-79$ & 758,713 & 1875 & 829731 & 0.914 \\
$1880-89$ & 90,832 & 1885 & 902831 & 0.101 \\
$1890-99$ & 574,609 & 1895 & 1026688 & 0.560 \\
$1900-09$ & 418,184 & 1905 & 1142165 & 0.366 \\
$1910-19$ & $10,143,283$ & 1915 & 1220527 & 8.311 \\
$1920-29$ & 426,874 & 1925 & 1309309 & 0.326 \\
$1930-39$ & $18,841,778$ & 1935 & 1484177 & 12.695 \\
$1940-49$ & $2,113,935$ & 1945 & 1610737 & 1.312 \\
$1950-59$ & $1,225,956$ & 1955 & 2525534 & 0.485 \\
$1960-69$ & $3,161,337$ & 1965 & 3268202 & 0.967 \\
$1970-79$ & $4,754,651$ & 1975 & 4035169 & 1.178 \\
$1980-89$ & $3,045,377$ & 1985 & 4869321 & 0.625 \\
$1990-97 *$ & $1,993,554$ & 1992 & 5426084 & 0.367 \\
\hline
\end{tabular}

*Indicates the death totals were normalized for a ten-year period for comparison purposes.

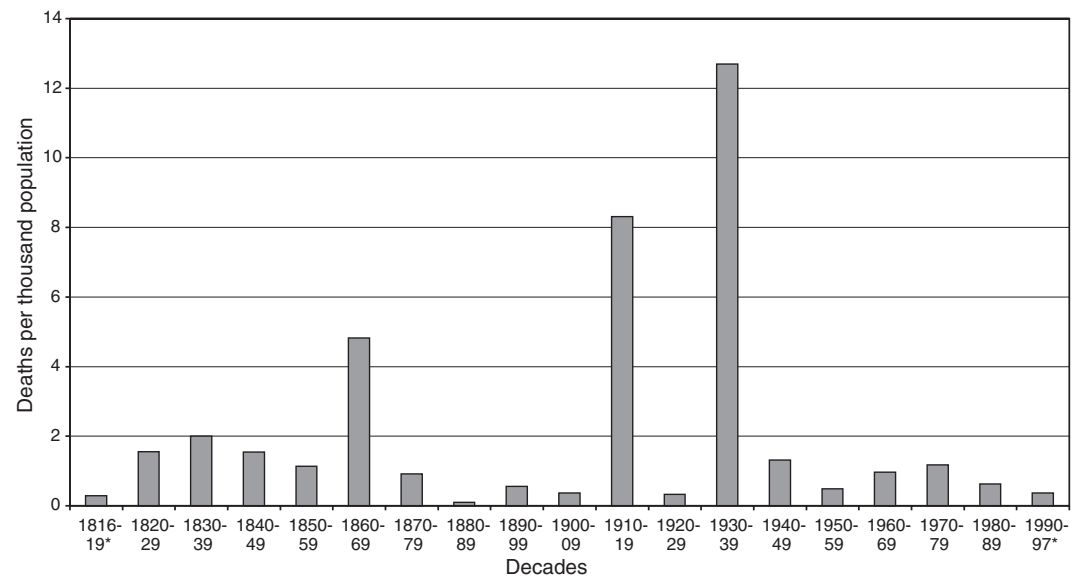

FIG. 6. War Deaths per Thousand Population

time is positive, though an insignificant .272. Though the total number of international (inter and extra-state) war onsets is negatively correlated with the increasing decades $(-.20)$, this finding is driven primarily by the decline in the frequency of extra-state wars (the correlation is -.419 , not significant). Conversely, both internationalized civil wars and civil wars overall are positively correlated with the passage of time $(.569$ significant at the .05 level and .720 significant at the .01 level, respectively).

Correlation analyses provide clues not only to the constancy of war, but also to the interplay among the types of war. If all types of war were in decline, there would be not only a negative correlation between war and the passage of time, but also positive correlations among the different types of war. In fact, an examination of the correlations among the various types of war reveal some very mixed patterns. While there is a negative correlation (of -.29 , not significant) between international 
war and civil war onsets, the correlation between inter-state wars alone and civil wars is actually positive, though not significant (.189). The statistically strongest finding here is the negative correlation between extra-state and civil wars (-.467, significant at the .05 level), demonstrating that when the states in the system are engaged in extra-state wars, the rate of civil wars is down (or vice versa). This inverse relationship suggests directions for future research, and might be evidence of a variety of different hypothetical processes. At an elemental level, both civil and extra-state wars can be tied to the increase in the number of state system members (which reduces the number of potential extra-state war participants, yet also increases the number of possible civil war locations). Alternatively, states with sufficient resources to attempt to take over colonies may also have sufficient resources to dampen civil conflict; or states may be using extra-state wars as a diversion against domestic turmoil; or conversely perhaps, states engaged in domestic conflict do not have resources for foreign adventures. Some of these patterns would be consistent with the thesis that types of war may be substituted for each other, and that reducing one type may just displace war into another equally bloody form. Indeed, the trend toward the increasing involvement of other states in "non-inter-state" wars (especially civil wars) further indicates the need to consider the commonalities and linkages between international and civil wars.

\section{Consequences and Conclusions}

The refined COW war typology provides a broad framework in which a comprehensive analysis of war can be conducted. It also provides the specificity of looking at war as a distinct phenomenon, differentiated from other types of conflict behavior. This distinguishes COW from many of the other data-gathering projects; most are more specific, either in terms of focusing upon shorter time frames, or in addressing only inter-state armed conflict (at war or crises levels). We hope that the redefinition of civil and extra-state wars will encourage research on these two types of war which have in the past received insufficient research attention. The original (and continued principal) focus of the COW Project has been on the operation of the international system, and specifically the identification of the factors that increased the risk of inter-state war. This focus was especially important for global security policy in the early years of the project when the nuclear war doomsday clock seemed only minutes from midnight. It is perhaps understandable, given such concerns, that, in contrast to virtually hundreds of publications related to the inter-state war data set, hardly any scholarship has examined the extra-state war data set. Consequently, most investigations of imperialism and colonialism remain anecdotal and qualitative rather than scientific and quantitative (for a recent exception see Goertz and Diehl, 1994). Yet extra-state wars do represent uses of force by system members beyond their borders. Scholars interested in an investigation of international wars are also encouraged to remain cognizant of internationalized civil wars, which also reflect states' willingness to use force outside the states' territory.

The disinclination to study extra-state wars in particular has, we believe, substantially distorted the ways in which we think about war and world politics. For example, it has been common to discuss the nineteenth century as a period of long peace ushered in by brilliant diplomacy at the Congress of Vienna (Kissinger, 1957). Blainey summarizes this convention ably when he says: "Historians' explanations of peace in modern times are centered on the nineteenth century. Two long periods in that century were remarkably peaceful. One ran from the Battle of Waterloo to the short wars of $1848 \ldots$... The other ... ran from the end of the Franco-Prussian War in 1871 to ... 1914" (1988:4). Levy (1983:43) demonstrated the empirical validity of these claims by showing that war involving at least one great power was under way 95 percent of the years in the sixteenth century and the seventeenth century, 71 
percent of the years of the eighteenth century, 53 percent of the years of the twentieth century, and only 29 percent of the years of the nineteenth century. But was this supposedly civilized, peaceful century just a time when Europeans stopped fighting each other to conquer and slaughter militarily weaker Asians and Africans? Our data indicate that there was only one brief "peaceful" period in the nineteenth century: all three types of war occurred with below-average frequency in the quarter-century after the Congress of Vienna (see Table 1). But the last quarter of the nineteenth century, seen as peaceful by some authors, had not only a slightly above average number of inter-state wars, but an all-time high incidence of extrasystemic wars (almost all in pursuit of imperial conquest).

These interpretations stem from, and in turn influence how we think of world politics. International war is often explained in "realist" terms as a result of security dilemmas arising from the pursuit of the national interest under conditions of global anarchy. This explanation of war, in turn, is used by the realpolitik school as evidence of the power of their paradigm: the balance of power at the end of the nineteenth century ensured its peace. However, would "anti-realist" explanations of war, emphasizing norms and sub-national interest groups (merchants, missionaries, and the military), be more prominent in world politics today if the cases we were explaining encompassed extra-state wars as well? Initial data analysis, looking only at colonial wars, has suggested that international norms are more potent than realpolitik in accounting for whether independence was granted peacefully or gained through fighting (Goertz and Diehl, 1994).

Neglect of extra-systemic war has many roots, from the high-minded to the racist (Hunt, 1987:18). Perhaps many of the same factors contribute to the lower priority assigned to the study of civil wars. Yet the long-ignored study of civil war and revolution was stimulated by the Vietnam War and the race riots in American cities in the 1960s (Gurr, 1970). The study of imperial and colonial wars has received no such boost from current events. Often, those with a normative concern over colonialism have been more interested in examining the enduring economic consequences of colonialism than in imperial and colonial war per se. The scientific explanation of modern war thus remained both fragmented and incomplete. With extra-systemic wars largely ignored, and civil wars largely relegated to study by scholars in the field of comparative politics, artificial divisions of scholarly attention have made it difficult to focus on overall trends in warfare and interrelations among the types of war. Perhaps if the explanation of inter-state war were Newtonian in its simplicity, power, and applicability, these problems would matter less, but with an ongoing need to accelerate advances in the study of inter-state war, there is a heuristic value in the fresh perspective that can be provided by a look at all modern international war, including extra-state and internationalized civil wars. We encourage further study of these questions: What are the implications of the trends of war? Are the increases in civil war and downturns in inter-state war a transient artifact of our own post-Cold War era, or, alternatively, reflect a more persistent transformation of global politics? Do the trends of globalization and fragmentation portend the emergence of a multiplicity of non-state actors with the ability to engage in warfare?

\section{References}

Bercovitch, J., AND R. Jackson (1997) International Conflict: A Chronological Encyclopedia of Conflicts and Their Management, 1945-1995. Washington, DC: Congressional Quarterly.

Blainey, G (1988) The Causes of War, 3rd ed. New York: Free Press.

Brecher, M., And J. Wilkenfeld (1997) A Study of Crisis. Ann Arbor: University of Michigan Press. Brecke, P. (1999) "The Characteristics of Violent Conflict since 1400 A.D." Paper presented at the annual meeting of the International Studies Association, Washington, D.C., Feb. 17-20.

Brogan, P. (1998) World Conflicts. Lanham, MD: The Scarecrow Press. 
Carment, D., And P. James (1997) Wars in the Midst of Peace: The International Politics of Ethnic Conflict. Pittsburgh, PA: University of Pittsburgh Press.

Cashman, G. (1993) What Causes War? New York: Lexington Books.

Cioffi-Revilla, C. (1990) Handbook of Datasets on Crises and Wars 1495-1988. Boulder, CO: Lynne Rienner.

Clodfelter, M. (1992) Warfare and Armed Conflicts: A Statistical Reference to Casualty and Other Figures 1618-1991. Jefferson, NC: McFarland.

Eberwein, W., And S. Chojnacki (2001) "Scientific necessity and political utility: A comparison of data on violent conflicts.” Discussion Paper P01-304. Berlin: Center for Social Science Research.

Fukuyama, F. (1989) The End of History? The National Interest 16(Summer):3-5, 8-15, 18.

Gaddis, J. L. (1987) The Long Peace: Inquiries into the History of the Cold War. New York: Oxford University Press.

Geller, D., And J. D. Singer (1998) Nations at War: A Scientific Study of International Conflict. Cambridge: Cambridge University Press.

Goertz, G., AND P. Diehl (1994) "International Norms and Power Politics." In Reconstructing Realpolitik, edited by F. Wayman and P. Diehl, pp. 101-122. Ann Arbor: University of Michigan Press.

Gurr, T. (1994) Peoples Against States: Ethnopolitical Conflict and the Changing World System. International Security 38:347-378.

Gurr, T. (1970) Why Men Rebel. Princeton, NJ: Princeton University Press.

Gurr, T., M. Marshall, and D. Khosla (2001) "Peace and Violent Conflict, 2001." College Park, MD: Center for International Development and Conflict Management.

Harff, B., AND T. Gurr (1988) Toward Empirical Theory of Genocides and Politicides: Identification and Measurement of Cases since (1945). International Studies Quarterly: 3:359-378.

Holsti, K. J. (1997) International Theory and Domestic War in the Third World: The Limits of Relevance. Paper presented at the annual meeting of the International Studies Association, Toronto, March 19-22.

Holsti, K. J. (1996) The State, War, and the State of War. Cambridge: Cambridge University Press.

Hunt, M. H. (1987) Ideology and U.S. Foreign Policy. New Haven, CT: Yale University Press.

Huntington, S. (1993) The Clash of Civilizations. Foreign Affairs 72:56-73.

Kaldor, M. (1999) New and Old Wars: Organized Violence in a Global Era. Stanford, CA: Stanford University Press.

Kegley, C. W., ED. (1991) The Long Postwar Peace. New York: HarperCollins.

Kissinger, H. (1957) A World Restored. Boston: Houghton Mifflin.

LAke, D. A., AND D. Rothchild, Eds. (1998) The International Spread of Ethnic Conflict. Princeton, NJ: Princeton University Press.

Levy, J. (1983) War in the Modern Great Power System. Lexington: University of Kentucky Press.

Levy, J., T. WAlker, AND M. Edwards (2001) "Continuity and Change in the Evolution of Warfare." In War in a Changing World, edited by Z. Maoz and A. Gat, pp. 15-48. Ann Arbor: University of Michigan Press.

Maoz, Z. V. (1997) The Controversy over the Democratic Peace. International Security 22:162-198.

Marshall, M. (1999) Third World War. Lanham, MD: Rowman and Littlefield.

Mearsheimer, J. (1990) Back to the Future: Instability in Europe after the Cold War. International Security 15:5-56.

Midlarsky, M. (1989) Handbook of War Studies. London: Unwin Hyman.

Midlarsky, M. (1988) Rulers and Ruled: Patterned Inequality and the Onset of Mass Political Violence. American Political Science Review 82:491-509.

Mueller, J. (1989) Retreat from Doomsday: The Obsolescence of Major War. New York: Basic Books.

Oneal, J., And B. Russett (1997a) The Classic Liberals Were Right: Democracy, Interdependence, and International Conflict, 1950-1985. International Studies Quarterly 41:267-293.

OnEAL, J., AND B. RussetT (1997b) Escaping the War Trap: Evaluating Liberal Prescriptions for Peace: Controlling for Expected Utility. Paper presented at the annual meeting of the International Studies Association, Toronto, March 19-22.

Rummel, R. J. (1994) Death by Government. New Brunswick, NJ: Transaction.

Russett, B. (1997) Evidence for the Kantian Peace: Democracy, Trade, and International Organizations, 1950-1992. Paper presented at the annual meeting of the International Studies Association, Toronto, March 19-22.

Sandole, D. (1999) Capturing the Complexity of Conflict: Dealing with Violent Ethnic Conflicts of the Post-Cold War Era. London: Pinter. 
Sarkees, M. R. (2000) Correlates of War Warsets: An Update. Conflict Management and Peace Science 18:123-144.

Sarkees, M. R., AND J. D. Singer (2001) Armed Conflict Past and Future: A Master Typology? Paper presented at the European Union Conference on Armed Conflict Data Collection, Uppsala, Sweden, June.

Scherrer, C. P. (1999) "Toward a Comprehensive Analysis of Ethnicity and Mass Violence: Types, Dynamics, Characteristics and Trends." In Ethnicity and Intra-state Conflict, edited by H. Wiberg and C. P. Scherrer. Aldershot, England: Ashgate Publishing Ltd.

Shemo, D. J. (1996) Oil Companies Buy an Army to Tame Colombia's Rebels. New York Times, Aug. 22, A1, A8.

SInGER, J. D. (1991) “Peace in the Global System: Displacement, Interregnum, or Transformation?” In The Long Postwar Peace, edited by C. Kegley, pp. 56-84. New York: HarperCollins.

Singer, J. D. (1969) “The Global System and Its Sub-Systems: A Developmental View." In Linkage Politics, edited by J. Rosenau, 21-43. New York: Free Press.

Singer, J. D., And M. Small (1972) The Wages of War, 1816-1965: A Statistical Handbook. New York: Wiley.

Singer, M., AND A. Wildavsky (1993) The Real World Order: Zones of Peace/Zones of Turmoil. Chatham, NJ: Chatham House.

Small, M., AND J. D. Singer (1982) Resort to Arms: International and Civil War, 1816-1980. Beverly Hills, CA: Sage.

Smith, D. (1997) The State of War and Peace Atlas, new edition. London: Penguin.

SNOW, D. M. (1996) Uncivil Wars. Boulder, CO: Lynne Rienner.

Vasquez, J. (1993) The War Puzzle. Cambridge: Cambridge University Press.

Wallensteen, P. (1984) Universalism vs. Particularism: On the Limits of Major Power Order. Journal of Peace Research 21:243-257.

Wallensteen, P., And K. Axell (1994) Conflict Resolution and the End of the Cold War, 1989-93. Journal of Peace Research 31:333-349.

WALTZ, K. (1979) Theory of International Politics. Reading, MA: Addison-Wesley.

Wayman, F., And P. Diehl (1994) "Realism Reconsidered: The Realpolitik Framework and Its Basic Propositions." In Reconstructing Realpolitik, edited by F. Wayman and P. Diehl, pp 3-26. Ann Arbor: University of Michigan Press. 